\title{
Review Article \\ Vitamin D Deficiency in HIV Infection: Not Only a Bone Disorder
}

\author{
Pasquale Mansueto, ${ }^{1}$ Aurelio Seidita, ${ }^{1}$ Giustina Vitale, ${ }^{1}$ Sebastiano Gangemi, ${ }^{2,3}$ \\ Chiara Iaria, ${ }^{4}$ and Antonio Cascio ${ }^{2,5}$ \\ ${ }^{1}$ Department of Internal Medicine and Biomedicine, University of Palermo, 90100 Palermo, Italy \\ ${ }^{2}$ Department of Human Pathology, University of Messina, 98125 Messina, Italy \\ ${ }^{3}$ IFC CNR, Messina Unit, 98100 Messina, Italy \\ ${ }^{4}$ Infectious Diseases Unit, Papardo-Piemonte Hospital, 98125 Messina, Italy \\ ${ }^{5}$ AILMI-ONLUS Italian Association for the Control of Infectious Diseases, University of Messina, 98125 Messina, Italy
}

Correspondence should be addressed to Antonio Cascio; acascio@unime.it

Received 19 November 2014; Revised 18 February 2015; Accepted 2 March 2015

Academic Editor: Daniel Teta

Copyright (C) 2015 Pasquale Mansueto et al. This is an open access article distributed under the Creative Commons Attribution License, which permits unrestricted use, distribution, and reproduction in any medium, provided the original work is properly cited.

\begin{abstract}
Hypovitaminosis D is a worldwide disorder, with a high prevalence in the general population of both Western and developing countries. In HIV patients, several studies have linked vitamin D status with bone disease, neurocognitive impairment, depression, cardiovascular disease, high blood pressure, metabolic syndrome, type 2 diabetes mellitus, infections, autoimmune diseases like type 1 diabetes mellitus, and cancer. In this review, we focus on the most recent epidemiological and experimental data dealing with the relationship between vitamin D deficiency and HIV infection. We analysed the extent of the problem, pathogenic mechanisms, clinical implications, and potential benefits of vitamin D supplementation in HIV-infected subjects.
\end{abstract}

\section{Introduction}

Human immunodeficiency virus type-1 (HIV) is a global health problem that has infected 60 million people and caused 25 million deaths worldwide. To date, it has been estimated that more than 33 million people, including 2 million children, live infected by HIV. However, even if the problem is far from a definitive solution, highly active antiretroviral therapy (HAART) has profoundly changed the natural history of HIV infection dramatically reducing AIDS- (acquired immune deficiency syndrome-) related morbidity and mortality [1]. Nevertheless, at least until now, HAART cannot eradicate HIV [2, 3]. Increased life expectancy exposes HIVinfected subjects both to chronic adverse drug reactions and to age-related morbidities, including neurocognitive disorders, cardiovascular and metabolic disease, renal and bone diseases (i.e., osteopenia/osteoporosis), and cancer [4-6]. Many of these appear to occur earlier in HIV patients compared to the general population. Key factors explaining premature age-associated non-AIDS-related events in patients receiving HAART are chronic inflammation and immune activation $[7,8]$ : plasma levels of several inflammatory and coagulopathy biomarkers, such as interleukin-6 (IL-6), highly sensitive C-reactive protein (hsCRP), and D-dimer are higher and correlate with outcome in HIV infection $[9,10]$.

Considering the potential role of vitamin D in many of these chronic illnesses, the scientific community focuses attention on the possible impact of its deficiency on the HIVinfected population. In this review, we first briefly describe vitamin D metabolism and its biological functions; then, we focus on the most recent epidemiological and experimental data dealing with the relationship between vitamin D deficiency and HIV infection. We analyse the extent of the problem, pathogenic mechanisms, clinical implications, and the potential benefits of vitamin D supplementation among HIVinfected subjects. We researched the PubMed database for the period from 1980 through January 31, 2015, using the keywords "HIV," "vitamin D," "neurocognitive disorders," "cardiovascular disease," "metabolic disease" (i.e., diabetes and metabolic syndrome), "renal disease," and "cancer." Articles 
presenting original data as well as reviews were included in our analysis.

\section{Prevalence of Hypovitaminosis $D$ in HIV-Infected Subjects}

Hypovitaminosis D is a worldwide disorder, with a high prevalence in the general population of both Western and developing countries. It has been estimated that more than 1 billion people suffer from either 25(OH)D (25-hydroxyvitamin D) deficiency or insufficiency. According to the results of the National Health and Nutrition Examination Survey (NHANES), 25(OH)D deficiency and insufficiency are at $79 \%$ among adults [11]. Thus, like the general population, it is not surprising to find high rates of hypovitaminosis $\mathrm{D}$ among HIV-infected subjects. The overall estimated prevalence in people living with $\mathrm{HIV}$ and $25(\mathrm{OH}) \mathrm{D}$ deficiency is high, ranging from 70.3 to $83.7 \%$ (Table 1).

Eckard et al. conducted an investigation on hypovitaminosis $\mathrm{D}$ and the possible variables associated with this pathological framework in HIV-infected pregnant women and their infants compared to healthy controls. It was found that $25(\mathrm{OH}) \mathrm{D}$ concentrations in serum cord blood were $<30 \mathrm{ng} / \mathrm{mL}$ in $100 \%$ of subjects from both groups. The only variables associated with higher serum $25(\mathrm{OH}) \mathrm{D}$ concentrations were white race and non-Hispanic ethnicity [12]. These data agreed with previous observations asserting that vitamin D deficiency not only contributes to HIV disease progression and mortality in HIV-infected pregnant women, but also increases the overall risk of mother-to-child transmission by $46 \%$ [13] and the risk of death in newborns by $61 \%$ during follow-up [13]. While most infants born to HIV-infected mothers in the US will not acquire HIV infection, in utero ART (antiretroviral therapy) exposure may increase their cancer risk later in life. Thus, maternal and therefore infant $25(\mathrm{OH}) \mathrm{D}$ deficiency should not be disregarded [14].

\section{Risk Factors for Vitamin D Deficiency in HIV-Infected Subjects}

In the setting of HIV infection, 25(OH)D deficiency may be affected by both HIV-related and -independent risk factors; however, it is often challenging to differentiate the direct impact of HIV infection from the effect of traditional risk factors which may be normal or overexpressed in HIVpositive cohorts.

3.1. HIV-Related Risk Factor. The relationship between $25(\mathrm{OH}) \mathrm{D}$ levels, viral load, and CD4+ T-cell count is not clear cut. Some studies described a positive correlation $[15,16]$, some others failed to demonstrate a significant association $[17,18]$, and, finally, others did not find that vitamin D (in any possible formula) supplementation can increase CD4+ count $[19,20]$. Different mechanisms have been hypothesized to explain the association between $25(\mathrm{OH}) \mathrm{D}$ deficiency and higher severity of HIV disease. First, 25(OH)D deficiency may be a contributory causal agent of the HIV infection itself.
Second, chronic inflammation due to HIV infection and subsequent TNF- $\alpha$ overproduction may be responsible for renal $1 \alpha$-hydroxylase impairment, reducing the PTH (parathyroid hormone) stimulatory effect on the production of the hormonally active 1,25(OH)2D (1,25-dihydroxyvitamin $\mathrm{D})$. Third, infectious complications as a result of poor immunity require hospital care, which significantly reduces the duration of sun exposure for patients. Lastly, both infectious complications and hospitalization may lead to malnutrition and reduced oral intake of the few foods that contain vitamin $\mathrm{D}$ $[21,22]$.

3.2. HIV-Independent Risk Factors. Several traditional hypovitaminosis D risk factors, such as female sex, increasing age, reduced exposure to sunlight, winter season, dark skin pigmentation, non-Caucasian race (i.e., African American ethnicity), greater body mass index (BMI), low vitamin D dietary intake, gastrointestinal absorption disorders, liver and renal diseases, multiple cardiovascular disease risk factors, including diabetes mellitus, and current alcohol consumption, are similar in both HIV-positive and HIV-negative cohorts [23, 24]. An exception is represented by intravenous drug use, which has not been extensively studied in the general population [25]. Injection drug users (IDUs) often have poor nutritional status and limited/delayed access to healthcare. In addition, intravenous drug use increases the risk for a host of acute and chronic infectious and cardiopulmonary conditions. As a result, this patient population suffers a disproportionate burden of $25(\mathrm{OH}) \mathrm{D}$ deficiency, compared to other urban dwelling adults [26, 27]. In 2014, Lambert et al. evaluated the relationship between intravenous drug use, 25(OH)D deficiency, and HIV infection, analysing 950 individuals (29\% of them were HIV-infected). The study found that $74 \%$ of subjects were $25(\mathrm{OH}) \mathrm{D}$ deficient $(68 \%$ in HIV-infected versus $76 \%$ in HIV-uninfected, $P=0.01)$; significantly, higher odds of $25(\mathrm{OH}) \mathrm{D}$ deficiency were observed in black race, late winter/early spring season, lack of multivitamin use, and hypoalbuminemia (the latter as an expression of poor nutritional state). Notably, HIV- and HCV-infected IDUs were less likely to be $25(\mathrm{OH}) \mathrm{D}$ deficient, evoking questions regarding the role of free vitamin $\mathrm{D}$ measurement (not influenced by albuminemia) in these unique populations [25].

\section{Vitamin D Status and HAART}

Recently several in vitro and in vivo studies focused on the impact of antiretroviral drugs on vitamin $\mathrm{D}$ metabolism. Both protease inhibitors (PIs) and nonnucleoside reverse transcriptase inhibitors (NNRTIs) have been associated with the impairment of vitamin D metabolic pathways [28-30].

PIs, especially darunavir and ritonavir, seem to interfere with vitamin $\mathrm{D}$ metabolism by inhibition of vitamin $\mathrm{D} 1 \alpha$ and $25 \alpha$-hydroxylation both in hepatocyte and in monocyte cultures: reduction of $25(\mathrm{OH}) \mathrm{D}$ conversion to its active metabolite may potentially explain the reports of increased $25(\mathrm{OH}) \mathrm{D}$ levels in subjects with low 1,25(OH)2D. Regarding NNRTIs, there is an increasing amount of experimental data 
要

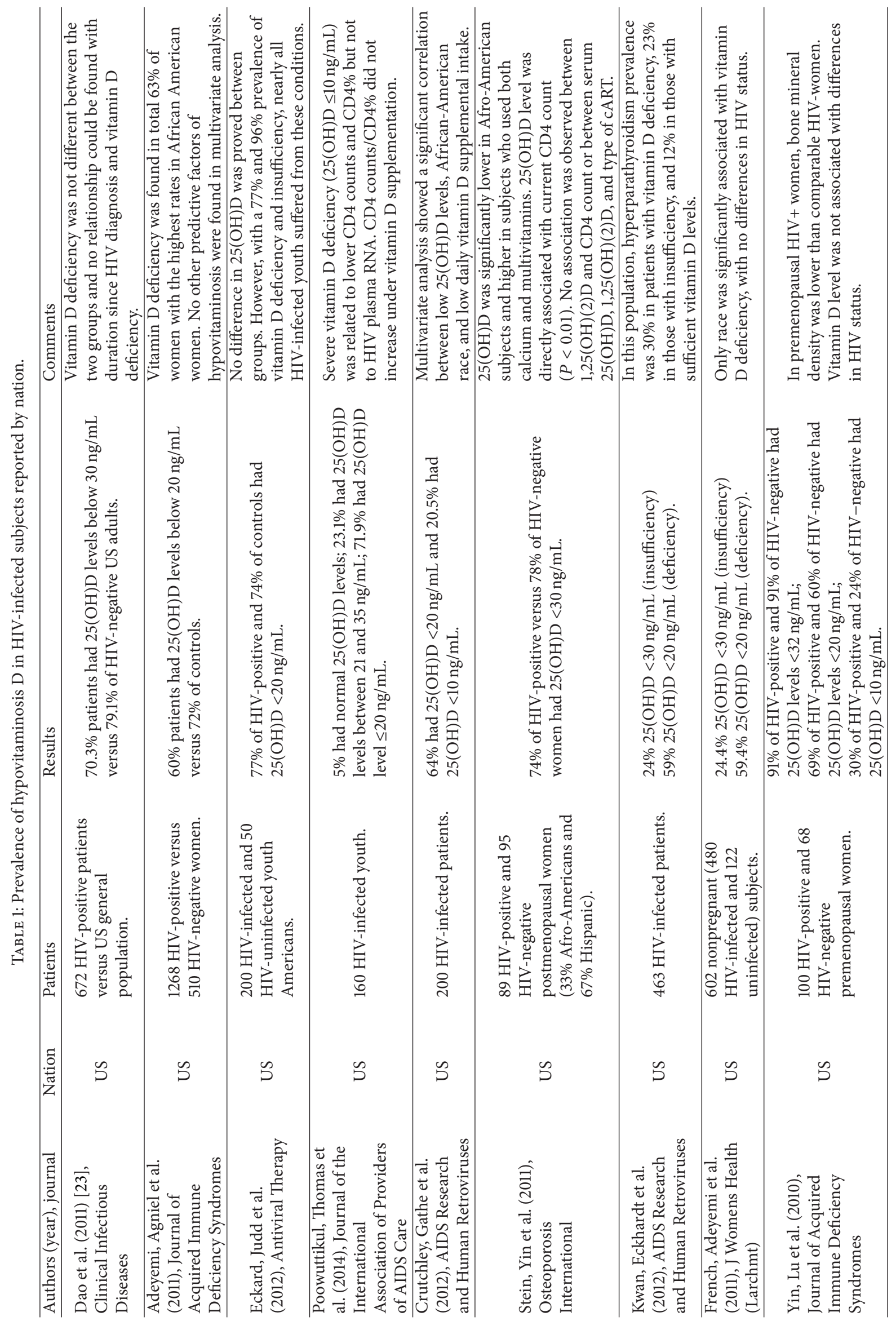




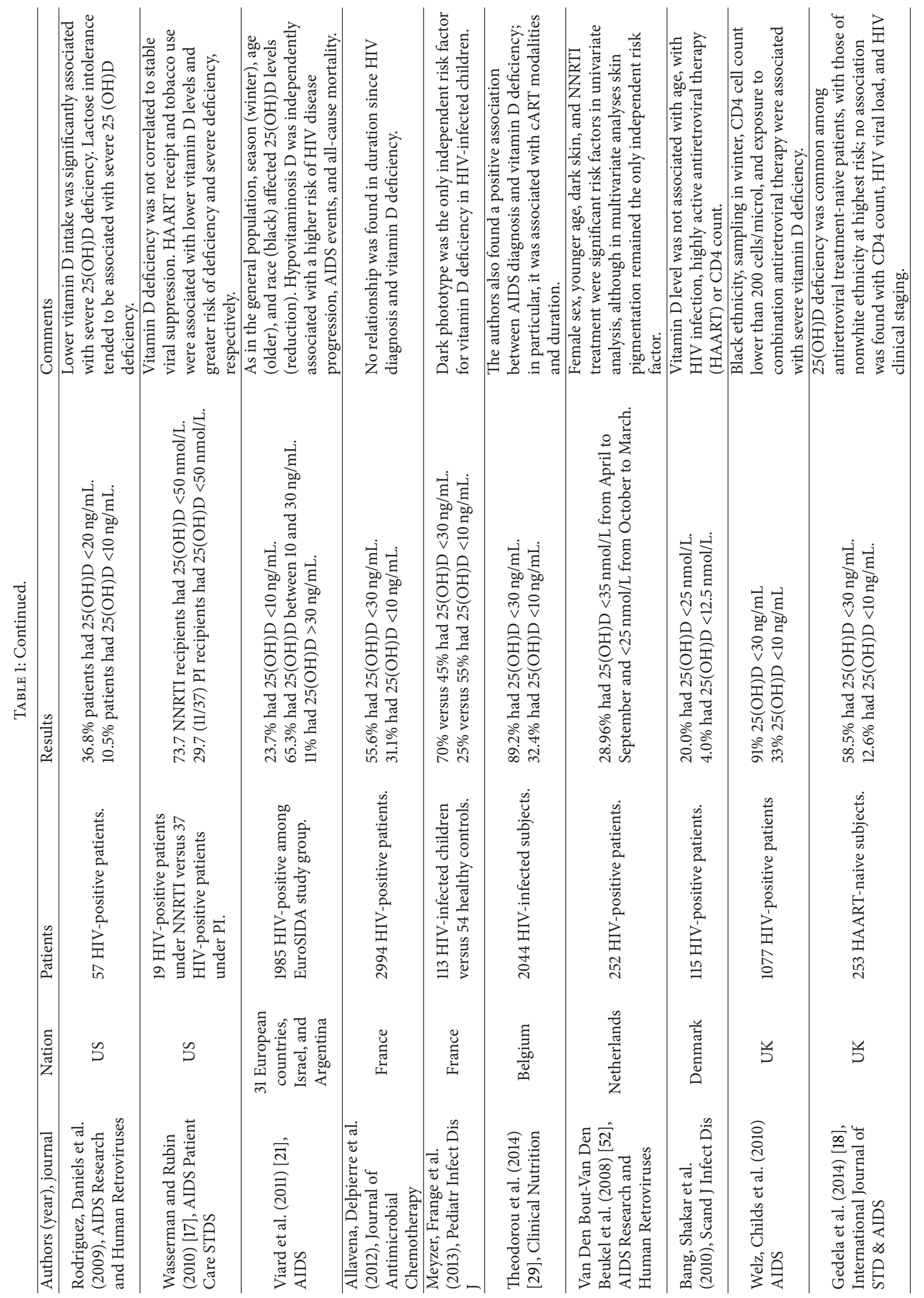




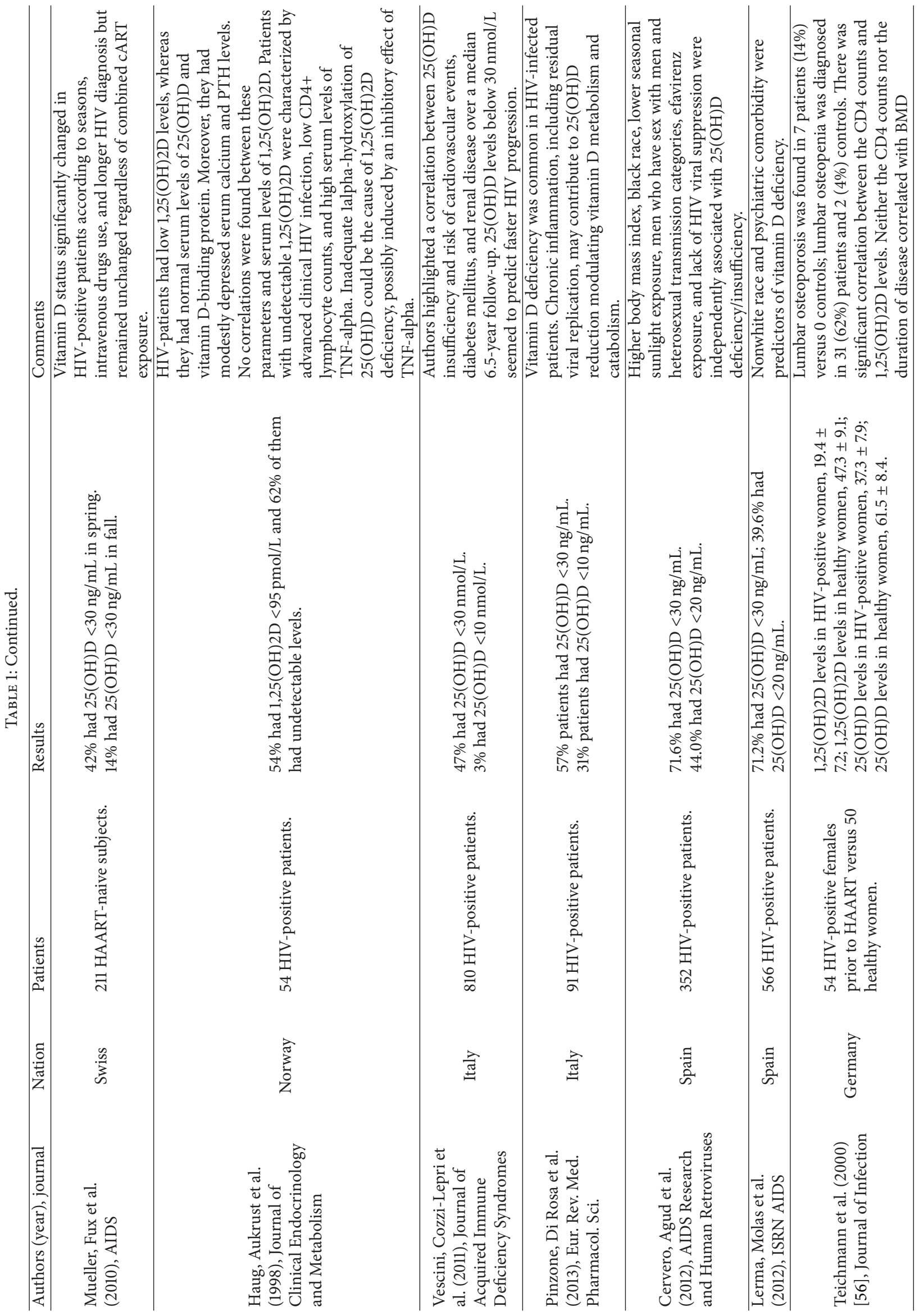




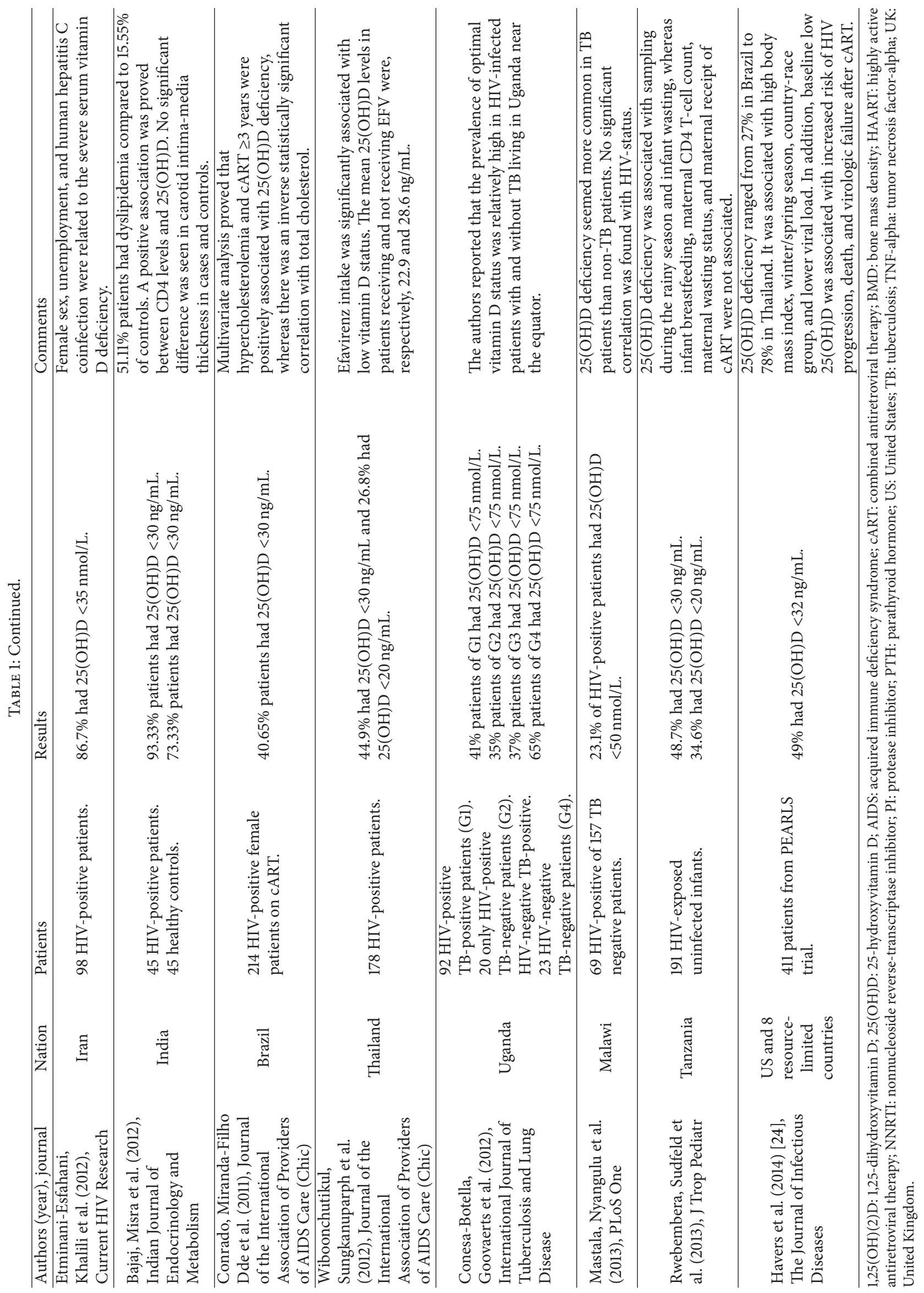


associating efavirenz (EFV). Unlike what was just reported for PIs, EFV seems to increase $25(\mathrm{OH}) \mathrm{D}$ catabolism and production of inactive metabolites, through the interaction with cytochrome P450 enzymes, some of which may affect vitamin D metabolism (i.e., induction of CYP24A1 [31, 32] and reduced transcription of CYP2R1), similar to the effects of antiepileptic drugs [33]. This hypothesis has been supported by several in vivo studies, which described an association between NNRTIs, especially EFV and nevirapine (NVP) use and low 25(OH)D levels (Table 2).

The weakness of most reported studies is the crosssectional design, so that causal relationships cannot be inferred. These data suggest the need for large prospective studies, properly designed to evaluate the specific effects and clinical impact of antiretroviral drugs on vitamin D status.

\section{Association between HIV, Hypovitaminosis D, and Cardiovascular Disease}

Several studies have described the association between HIV and increased risk of CVD (cardiovascular disease) [34, 35]. HIV infection itself is considered an independent risk factor for atherosclerosis: the prevalence of carotid intima-media thickness (cIMT), atherosclerosis, and myocardial infarction is higher among HIV-positive subjects, occurring earlier compared to uninfected individuals $[36,37]$. In these patients atherogenesis is enhanced by several factors: HIV-induced chronic inflammation and immune activation (demonstrated by increased levels of proinflammatory cytokines and endothelial activation markers), excess of traditional risk factors (e.g., 2 to 3 times higher prevalence of smoking), and antiretroviral drug-related dyslipidemia, hyperglycemia, central obesity, and lipodystrophy (especially with PIs) [38-40]. To make this framework even more complex, $1,25(\mathrm{OH}) 2 \mathrm{D}$ deficiency has been linked to CVD in the general population [41, 42]. Vitamin D influences cardiovascular health by suppressing the renin-angiotensin system and stimulating cellular proliferation and differentiation via $1,25(\mathrm{OH}) 2 \mathrm{D}$ binding to vitamin $\mathrm{D}$ receptors in the heart, the endothelium, and the vascular smooth muscle $[43,44]$.

5.1. cIMT, Brachial Artery Flow-Mediated Dilation, Coronary Artery Calcium (or Calcification), and Coronary Artery Stenosis. Considering the high prevalence of both hypovitaminosis D and CVD in patients with HIV, the evidence of a relationship between low 25(OH)D and silent and symptomatic atherosclerosis is not surprising. Even though in the general population asymptomatic CVD, as demonstrated by cIMT, brachial artery flow-mediated dilation (FMD, an early marker of endothelial dysfunction), and CAC (coronary artery calcification), has been strongly linked to the occurrence of cardiovascular events and has also been independently associated with $25(\mathrm{OH}) \mathrm{D}$ deficiency, only a few studies are available in HIV-infected populations; moreover, none of these studies shows if $25(\mathrm{OH}) \mathrm{D}$ repletion might affect cardiovascular outcomes. The clinical characteristics of the populations, the study designs, and the variables included in the analysis of results could explain the differences among the studies [45-47] (Tables 3 and 4).

5.2. Other Risk Factors for CVD in HIV-Infected Subjects. Other traditional risk factors for CVD, such as insulin resistance and diabetes mellitus, are frequently seen in HIVpositive individuals [48], and, as in the general population [49], an association between vitamin D status and type 2 diabetes, but not with insulin resistance, has been described [50, 51]. A recent Italian cross-sectional study of $1811 \mathrm{HIV}$-infected persons, enrolled in the prospective Modena (Italy) HIV Metabolic Clinic Cohort, reported lower 25(OH)D levels in subjects with Type 2 diabetes, compared to those without diabetes $(P<0.001)$, although $25(\mathrm{OH}) \mathrm{D}$ deficiency was highly prevalent in both groups. In addition, although $25(\mathrm{OH}) \mathrm{D}$ deficiency was independently associated with diabetes (OR 1.85; CI 1.03-3.32, $P=0.038$ ), the association with metabolic syndrome was not significant after adjusting for vitamin D supplementation, sex, age, and BMI (adjusted OR 1.32; 95\% CI 1.00-1.75; $P=0.053$ ) [50]. In the setting of HIV few data are available and the effects of vitamin $\mathrm{D}(3)$ supplementation on insulin sensitivity need to be evaluated with large, prospective studies. However, surprising results were provided by a small prospective study conducted by van den Bout-van den Beukel et al., which showed that cholecalciferol supplementation (2,000 IU/day for 14 weeks, 1,000 IU/day until 48 weeks) led to increased HOMA measured insulin resistance, after 24 weeks, whereas no differences were seen after 48 weeks [52]. It remains to be clarified whether the results are dose- or time-dependent, but this report further suggests the importance of clinical trials extensively evaluating the pros and cons of supplementing HIV-infected individuals with cholecalciferol [52].

\section{Association between HIV, Hypovitaminosis D, and HIV Disease Progression}

Preclinical experiments have demonstrated that treatment of peripheral blood mononuclear cells with 1,25(OH)2D decreased the cell susceptibility to HIV infection by inhibiting viral entry, modulating expression of CD4+ cell surface antigen, damping viral p24 production, and limiting monocyte proliferation $[53,54]$. Thereafter, several observational studies have shown a significant association between higher levels of $25(\mathrm{OH}) \mathrm{D}$ and rates of immune recovery $[15,55,56]$. Along these lines, some authors investigated the association between vitamin $\mathrm{D}$ and clinical outcomes. Baseline $25(\mathrm{OH}) \mathrm{D}$ levels lower than $32 \mathrm{ng} / \mathrm{mL}$ were independently associated with progression to more advanced HIV stage among $884 \mathrm{HIV}$-infected pregnant women in Tanzania, who were followed for a median of 70 months. The women with $25(\mathrm{OH}) \mathrm{D}$ in the highest quintile had a $42 \%$ lower risk of allcause mortality than the women in the lowest quintile [13]. The same authors demonstrated that 25(OH)D deficiency was also associated with low BMI, oral thrush, acute upper respiratory infections, and severe anemia [57]. However, other studies failed to demonstrate an association between 


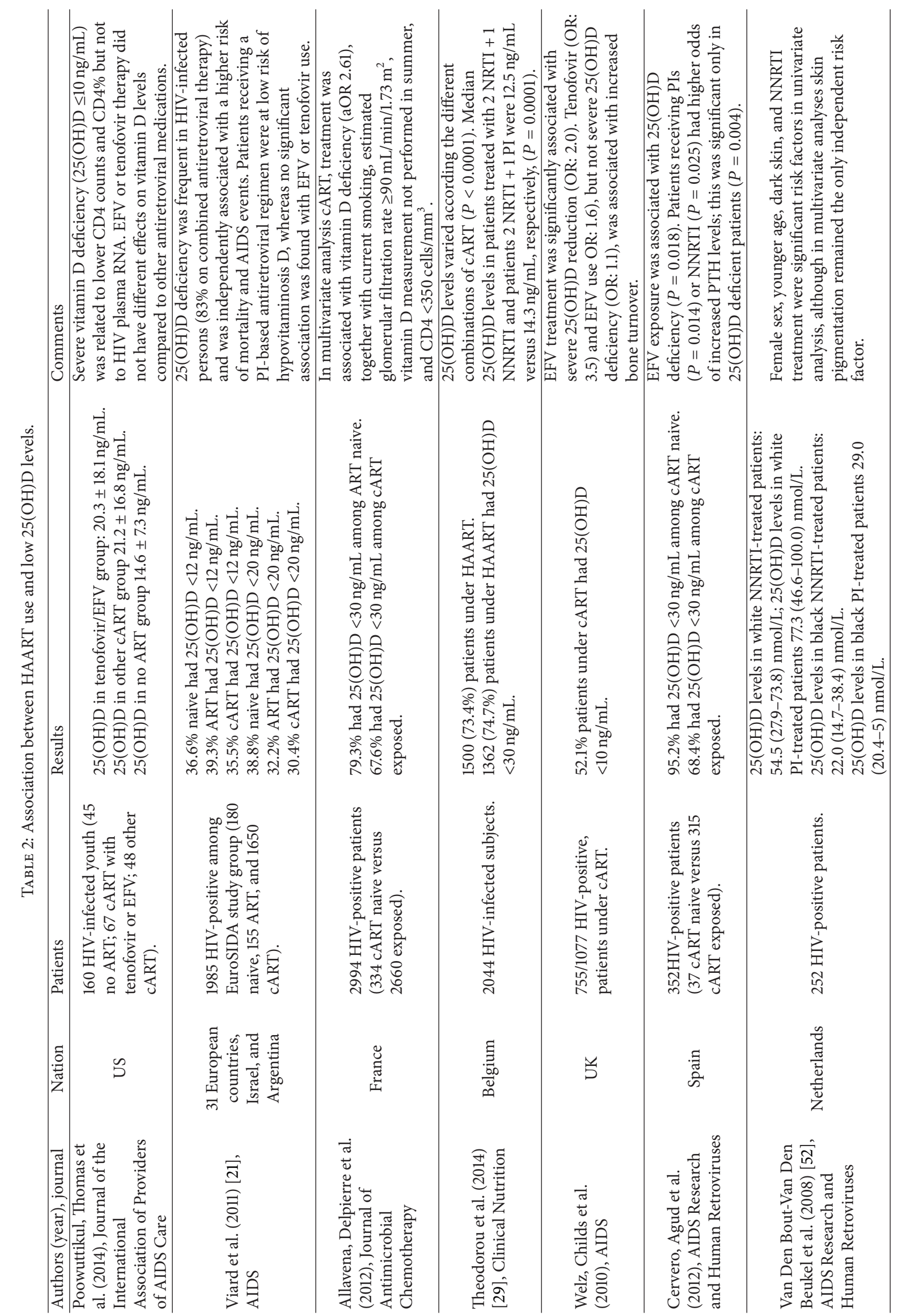




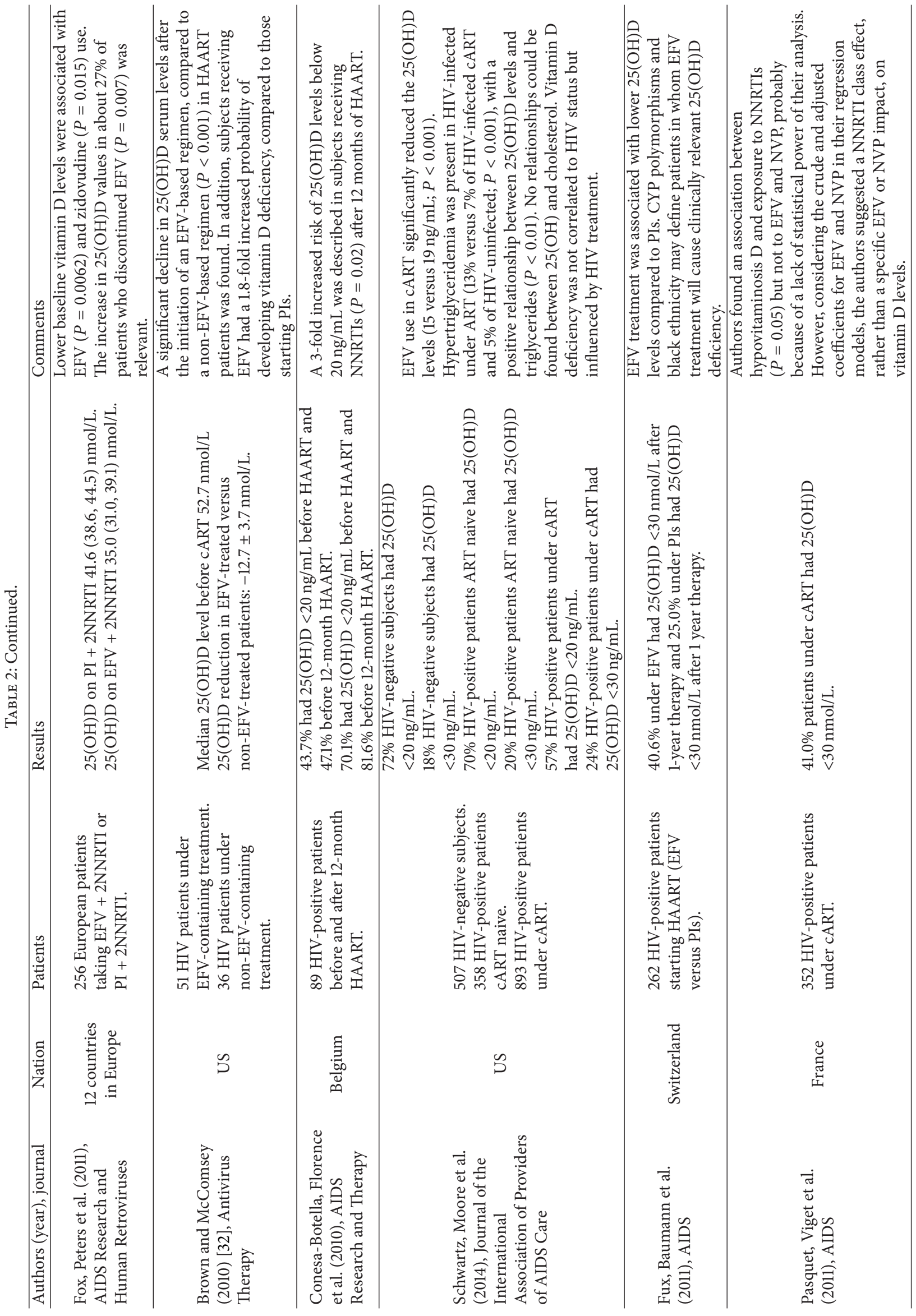









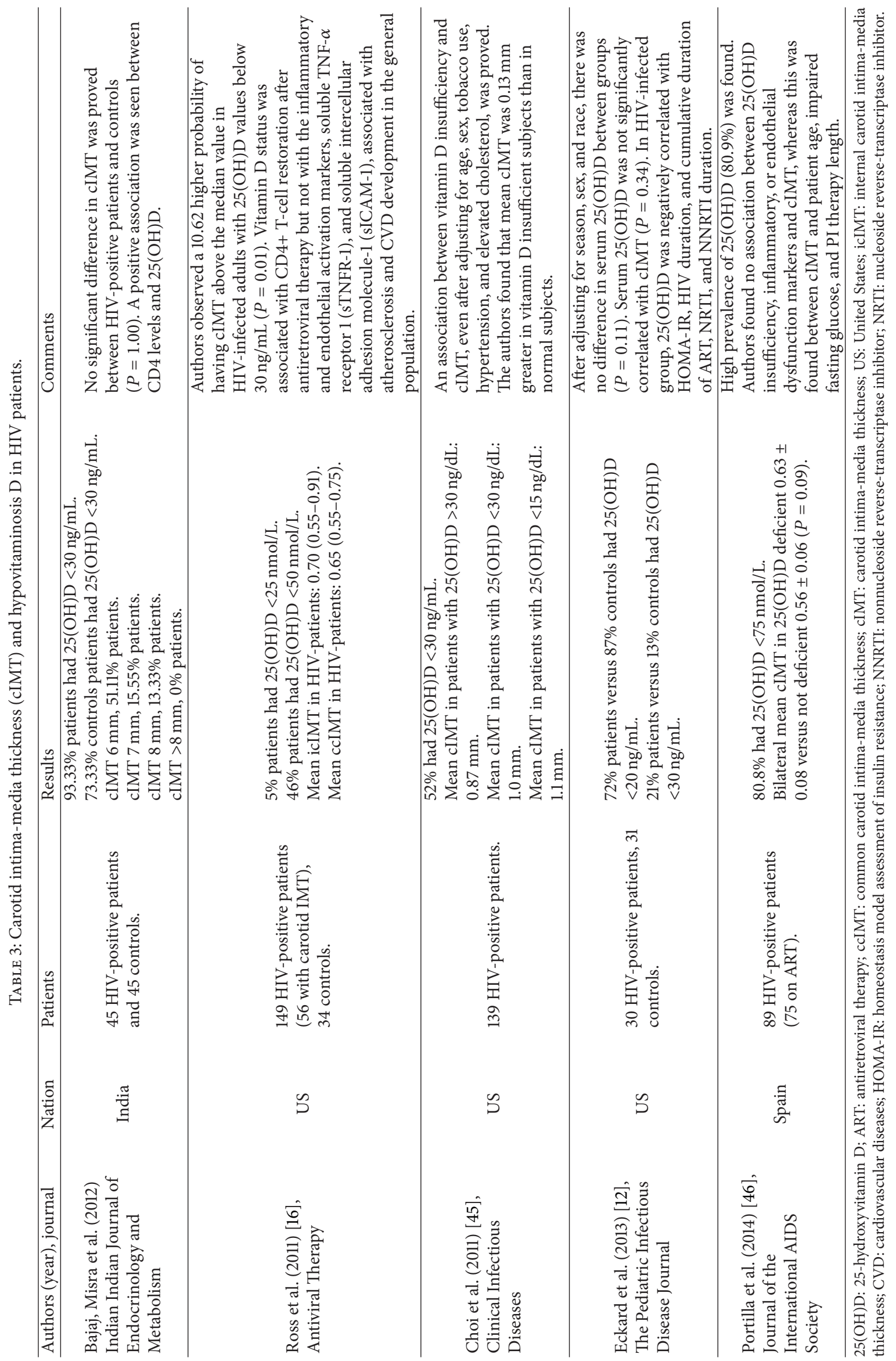


TABLE 4: Brachial artery flow-mediated dilation, coronary artery calcium (or calcification) and hypovitaminosis D in HIV patients.

\begin{tabular}{|c|c|c|c|c|}
\hline Authors (year), journal & Nation & Patients & Results & Comments \\
\hline $\begin{array}{l}\text { Lai et al. (2013) [47], } \\
\text { Vascular Health and } \\
\text { Risk Management }\end{array}$ & US & $\begin{array}{l}846 \mathrm{HIV} \text {-infected } \\
\text { African-American } \\
\text { participants. }\end{array}$ & $28.1 \%$ had CAC. & $\begin{array}{l}\text { Logistic regression analysis revealed the } \\
\text { factors independently associated with } \\
\text { CAC: age, male sex, family history of } \\
\text { CAD, years of cocaine use, total } \\
\text { cholesterol, high-density lipoprotein } \\
\text { cholesterol, PI treatment length, and, } \\
\text { finally, vitamin D deficiency. }\end{array}$ \\
\hline
\end{tabular}
finally, vitamin D deficiency.

$\begin{array}{lcll}\begin{array}{l}\text { SShikuma, Seto et al. } \\ \text { (2012), AIDS Research }\end{array} & \text { US } & \text { 100 patients of the } & \text { MIV- } \\ \text { and Human Retroviruses } & \text { (Hawaii) } & \begin{array}{l}\text { Cardiovascular } \\ \text { Cohort Study }\end{array} & \text { 27.9 ng/mL. } \\ & & \text { CAC was present in } 53 \% .\end{array}$

A significant correlation was observed between 25(OH)D levels and FMD $(P=0.01)$ but not with $\operatorname{cIMT}(P=0.76)$. Lower $25(\mathrm{OH}) \mathrm{D}$ levels were at slightly higher risk of having CAC $(P=0.04)$; these lower 25(OH)D levels were not associated with higher CAC scores $(P=0.36)$.

\begin{tabular}{|c|c|c|c|c|}
\hline $\begin{array}{l}\text { Gepner, Ramamurthy et } \\
\text { al. (2012), PLoS One }\end{array}$ & US & $\begin{array}{l}114 \text { healthy } \\
\text { postmenopausal } \\
\text { women ( } 54 \text { treated } \\
\text { with vitamin D } \\
\text { supplementation } \\
\text { and } 57 \text { with } \\
\text { placebo). }\end{array}$ & $\begin{array}{l}\text { Median pretreatment } \\
25(\mathrm{OH}) \mathrm{D} 30.3 \text { in treatment } \\
\text { group, } 32.3 \text { in placebo } \\
\text { group. } \\
\text { FMD pretreatment } 0.018 \mathrm{in} \\
\text { treatment group, } 0.016 \mathrm{in} \\
\text { placebo group. } \\
\text { FMD posttreatment } 0.001 \\
\text { in treatment group, } 0.001 \text { in } \\
\text { placebo group. }\end{array}$ & $\begin{array}{l}\text { Authors proved no improvement in } \\
\text { endothelial function, arterial stiffness (as } \\
\text { measured by brachial artery FMD, } \\
\text { carotid-femoral pulse wave velocity, and } \\
\text { aortic augmentation index), or } \\
\text { inflammation markers after vitamin D } \\
\text { supplementation in the general } \\
\text { population. }\end{array}$ \\
\hline $\begin{array}{l}\text { de Boer, Kestenbaum et } \\
\text { al. (2009), Journal of the } \\
\text { American Society of } \\
\text { Nephrology }\end{array}$ & US & $\begin{array}{l}1370 \text { HIV-negative } \\
\text { patients ( } 394 \text { with } \\
\text { and } 976 \text { without } \\
\text { CKD). }\end{array}$ & $\begin{array}{l}53 \% \text { had CAC at baseline } \\
\text { ( } 65 \% \text { with CKD and } 48 \% \\
\text { without CDK). } \\
21 \% \text { of subjects who do not } \\
\text { have CAC at baseline } \\
\text { developed it during 3-year } \\
\text { follow-up. }\end{array}$ & $\begin{array}{l}\text { Lower } 25(\mathrm{OH}) \mathrm{D} \text { concentration was } \\
\text { associated with increased risk for CAC } \\
\text { development; each } 10 \mathrm{ng} / \mathrm{mL} 25(\mathrm{OH}) \mathrm{D} \\
\text { reduction there was a } 23 \% \text { increased risk } \\
(P=0.049) .\end{array}$ \\
\hline
\end{tabular}

25(OH)D: 25-hydroxyvitamin D; CAC: coronary artery calcification; cIMT: carotid intima-media thickness; CKD: chronic kidney disease; FMD: artery flowmediated dilation; PI: protease inhibitor; US: United States.

$25(\mathrm{OH}) \mathrm{D}$ level and clinical outcome, as in the above mentioned study by Sherwood et al. [58].

\section{Association between HIV, Hypovitaminosis $D$, and Hepatitis C}

HCV (hepatitis $\mathrm{C}$ virus) infection occurs at a significantly higher rate in HIV-infected persons compared to the general population, and this is especially problematic for resourcelimited settings, where HCV treatment is generally not easily available [59]. HIV has a negative impact on the natural history of HCV, and, compared to HCV monoinfected patients, $\mathrm{HIV} / \mathrm{HCV}$ coinfected patients have a more rapid progression from chronic active hepatitis to liver-cirrhosis, end-stage liver disease, liver cancer, and death, as well as lower response rate to traditional HCV treatment $[60,61]$. Male sex, insulin resistance, acquiring $\mathrm{HCV}$ at an older age, heavy alcohol consumption, HCV genotype 3, and low CD4+ cell count are the factors contributing to the rapid development of liver fibrosis/cirrhosis among HIV/HCV coinfected patients [62,
63]. Other studies of HCV monoinfected patients have shown an independent association of $25(\mathrm{OH}) \mathrm{D}$ deficiency with severe liver fibrosis and treatment failure [64].

$1,25(\mathrm{OH}) 2 \mathrm{D}$ effects on the immune system and inflammatory response have been shown to directly inhibit the proliferation and profibrotic effect of hepatic stellate cells [65]. Not surprisingly, liver fibrosis is associated with low serum levels of $25(\mathrm{OH}) \mathrm{D}$ during both $\mathrm{HBV}$ - and HCV-related chronic hepatitis, in both HIV-coinfected and not-coinfected patients [66]. However, low levels of $25(\mathrm{OH}) \mathrm{D}$ have been found in HBV or HCV carriers with minimal or absent liver fibrosis compared to healthy subjects [67].

On the other hand, in HIV-HCV coinfected patients, studies investigating the association between HCV sustained virologic response and vitamin $\mathrm{D}$ level have reported varying results, with some studies demonstrating an association [68], whereas other studies do not [69]. Mandorf et al. demonstrated that serum levels of $25(\mathrm{OH}) \mathrm{D}$ may predict the response to anti-HCV therapy. Suspicion of such a connection is strengthened by the evidence that cholecalciferol supplementation improves early and sustained virological 
response ( $94 \%$ versus $48 \%$ in controls and $86 \%$ versus $42 \%$ in controls, resp.) in HCV genotype 1 patients treated with PegIFN/ribavirin [70, 71]. The exact mechanism of its antiviral (anti-HCV) effect is unknown, although it was recently shown to amplify the innate antiviral immune response upregulating IFN- $\beta$ and the MxA (an IFN-induced human protein) gene expression and dampening interferon gammainduced protein 10 (IP-10) expression [72].

\section{Association between HIV, Hypovitaminosis $D$, and Tuberculosis}

According to the World Health Organization approximately 2 billion people are exposed to $M$. tuberculosis, 8 million people per year are infected, and 2 million people die as a clinical outcome [73]. HIV is the strongest factor in the development of active TB (tuberculosis), and its spread has fuelled the resurgence of the TB epidemic. It has been proposed that in HIV infection $M$. tuberculosis escapes the local immune response within the granulomas, decreasing their containing ability and then leading to increased mycobacterial replication, dissemination, and clinical disease [74]. The rise in CD4+ count and improved immune function after HAART initiation partially restore pathogen specific immunity. In the general population, 25(OH)D levels lower than $4 \mathrm{ng} / \mathrm{mL}$ were shown to cause a 3-fold probability of having active TB [75], with higher risk of developing MDR $M$. tuberculosis infection [76]. A cross-sectional study of $174 \mathrm{HIV}$-infected and 196 HIV-uninfected individuals in Cape Town, South Africa, showed that $25(\mathrm{OH}) \mathrm{D}$ deficiency is independently associated with active TB and this association is greater in HIVinfected subjects [77]. A prospective Tanzanian cohort study enrolled $1103 \mathrm{HIV}$-infected persons initiating HAART in a randomized controlled trial (RCT) of vitamin D-free multivitamin supplementation. Baseline $25(\mathrm{OH}) \mathrm{D}$ levels lower than $20 \mathrm{ng} / \mathrm{mL}$, but not 25(OH)D insufficiency, were associated with higher incident smear-positive $\mathrm{TB}$, after a median follow-up of 20.6 months, wasting, and $>10 \%$ weight loss but not with risk of malaria, pneumonia, or anaemia. Mortality hazard ratio was 2.0 for those with levels below $20 \mathrm{ng} / \mathrm{mL}$ versus those with levels above $30 \mathrm{ng} / \mathrm{mL}$ over 24 months. Reverse causality (i.e., that vitamin D deficiency occurred as a result of $\mathrm{TB}$ ) was ruled out in this study by the exclusion of patients who developed TB within 1 month of enrolment. This finding is significant, since TB itself might contribute to vitamin $\mathrm{D}$ deficiency by reducing a patient's sun exposure or increasing consumption of $25(\mathrm{OH}) \mathrm{D}$ by activated macrophages [78]. Recently a systematic review was conducted to analyse studies published from 1980 to 2006 with data on serum $25(\mathrm{OH}) \mathrm{D}$ in pulmonary $\mathrm{TB}$ patients and controls. Five out of seven case-control studies, with a total of 531 participants, reported lower serum 25(OH)D in cases compared to controls. Several weaknesses were found: the sample sizes were small, ranging between 30 and 145 participants; some studies did not use culture for diagnosing TB; some studies included extrapulmonary TB; selection of controls was not optimal [79].

\section{Association between HIV, Hypovitaminosis D, Chronic Inflammation, and Malignancy}

9.1. Chronic Inflammation. HIV infection is associated with chronic inflammation (i.e., elevated TNF, IL-6, and CRP) and immune system activation (i.e., increased soluble CD14 and CXCL10), even after achieving full virologic suppression and immune recovery with the use of HAART $[80,81]$. In this population, elevation of inflammation markers has been shown to be independent predictors of neurocognitive impairment, frailty, cardiovascular events, diabetes and metabolic syndrome, low BMD, malignancies, and all-cause mortality [82-85]. The same outcomes, including all-cause mortality, were also associated with chronic inflammation in the general population [86]. Thus, there seems to be a considerable overlap in the outcomes associated with $25(\mathrm{OH}) \mathrm{D}$ deficiency and chronic inflammation, in both the HIV-infected and HIVuninfected populations.

9.2. Malignancy. Association of vitamin $\mathrm{D}$ deficiency with risk of cancer in the HIV-infected population remains to be determined. However, it has already been shown in the general population, including breast cancer (4-fold risk) [87], colon cancer (2-fold risk) [88], ovarian cancer (4-fold risk) [89], and prostate cancer (3-fold risk) [90]. However, to date, there is only one study that tried to correlate $25(\mathrm{OH}) \mathrm{D}$ deficiency, HIV, and cancer. Erlandson et al. enrolled $90 \mathrm{HIV}$ infected patients with AIDS-associated Kaposi's sarcoma (KS) from Zimbabwe, in a prospective pilot study investigating the effect of antiretroviral therapy on the natural history of this neoplasm. The authors demonstrated that $25(\mathrm{OH}) \mathrm{D}$ insufficiency was common and HIV-1 RNA was significantly higher in those with insufficient $25(\mathrm{OH}) \mathrm{D}$; in contrast, tumor response, survival, and KS-associated immune reconstitution inflammatory syndrome (defined as any progression of $\mathrm{KS}$ occurring $\leq 12$ weeks after initiation of HAART) were generally associated with an increased CD4+ lymphocyte count of at least 50 cells/mL above the baseline value, before or at the time of documented KS progression, and were not associated with 25(OH)D status [91].

\section{Management of Hypovitaminosis $D$ in HIV-Positive Individuals}

10.1. Screening. The main arguments in favor of routine screening of vitamin D in HIV-infected patients include the potential optimization of skeletal, metabolic, and immunologic parameters with vitamin D supplementation. The arguments against routine screening include assay variability and costs, lack of a clear target range, absence of proven supplementation benefits, apart from the benefits connected with osteoporosis as in the general elderly population, limited randomized clinical trial data in HIV-infected patients, inability to distinguish the effects of vitamin $\mathrm{D}$ and calcium supplementation on bone, potential harm from some supplementation approaches, and increased pill regimen (possible reduction of patient compliance). 
The European AIDS Clinical Society most recent guidelines suggest vitamin $\mathrm{D}$ status evaluation in patients with a history of low BMD or fracture, those with high risk of fracture, or those with other vitamin D deficiency associated factors (e.g., persons receiving some antiretroviral drugs, including EFV). Vitamin D replacement is recommended when $25(\mathrm{OH}) \mathrm{D}$ is lower than $10 \mathrm{ng} / \mathrm{mL}$; for values ranging between 10 and $20 \mathrm{ng} / \mathrm{mL}$, supplementation is recommended only for patients with osteomalacia, osteoporosis, or increased PTH [92]. McComsey et al. developed recommendations for bone disease in HIV infection, addressing vitamin D deficiency as well. They recommend 50,000 IU of cholecalciferol weekly for 8 to 12 weeks and then monthly thereafter or 2,000 IU daily for 12 weeks and then 1,000 to 2,000 IU daily thereafter. $25(\mathrm{OH}) \mathrm{D}$ levels after replacement should be measured. They recommend supplementation to achieve $25(\mathrm{OH}) \mathrm{D}$ greater than $32 \mathrm{ng} / \mathrm{mL}$ [93].

10.2. Supplementation. In the general population, recommendations regarding vitamin D supplementation are mostly derived from studies on bone health. Several large RCTs found beneficial effects of vitamin $\mathrm{D}$ plus calcium on BMD and fracture risk [94]. Meta-analyses showed that vitamin D (cholecalciferol) plus calcium association is superior to the use of a single drug in fracture prevention [94]. Unfortunately, the evidence for vitamin $\mathrm{D}$ use in clinical outcomes beyond skeletal health (i.e., on falls, CVD, diabetes, metabolic syndrome, immune response, and cancer) is inconsistent with and insufficient to base general recommendations.

10.2.1. Vitamin D Supplementation Dosage. In the general population, current recommended vitamin D oral supplementation is $800-1,000 \mathrm{IU}$ cholecalciferol/day, plus calcium $1000 \mathrm{mg}$ to $1200 \mathrm{mg}$ daily. Serum 25(OH)D levels generally increase by approximately $1 \mathrm{ng} / \mathrm{mL}$ for every $100 \mathrm{IU}$ of cholecalciferol intake. Few data from small cohorts are available on the efficacy of cholecalciferol repletion in HIV-infected subjects [95]. However, in this subgroup, it seems that a daily intake of at least 1,000-2,000 IU/day may be needed to overcome vitamin D deficiency [29].

10.2.2. Safety of Vitamin D Supplementation. Groleau et al. demonstrated that supplementation with high vitamin $\mathrm{D}(3)$ doses and the concomitant increased serum 25(OH)D level did not correlate with increased whole blood lead concentration in HIV-infected children and young adults. Vice versa, the more robust increase in serum $25(\mathrm{OH}) \mathrm{D}$ after 12 weeks of vitamin $\mathrm{D}(3)$ supplementation for participants enrolled during winter and spring was accompanied by a decrease in whole blood lead concentration [96]. Animal studies show an inverse relationship between calcium intake and lead levels. This inverse relationship was also found in pregnant women, and calcium supplementation during pregnancy was associated with reductions in blood lead. Overall, the above data provide safety information when considering higher dose vitamin D intervention [97].
10.2.3. Extraskeletal Effects of Vitamin D Supplementation. There are only a few studies investigating the effect of cholecalciferol supplementation on other cardiovascular, metabolic, and immunological outcomes in the HIV-infected population. In an RCT involving 45 subjects with $25(\mathrm{OH}) \mathrm{D}$ lower than $20 \mathrm{ng} / \mathrm{mL}$, 12-week supplementation with daily oral cholecalciferol 4,000 IU produced an increase of approximately $5 \mathrm{ng} / \mathrm{mL}$ in $25(\mathrm{OH}) \mathrm{D}$ level compared to placebo but did not result in a statistically significant change in brachial artery FMD. Moreover, in the study group, insulin resistance increased from baseline but it was not statistically different from the placebo arm; similarly, baseline inflammatory and coagulation markers (i.e., CRP, IL-6, sTNFR-1, ICAM, vascular cell adhesion molecule (VCAM), D-dimer, and fibrinogen) did not significantly change between the groups. These results could partly be attributed to the modest increase in $25(\mathrm{OH}) \mathrm{D}(5 \mathrm{ng} / \mathrm{mL})$ in subjects receiving cholecalciferol supplementation [98]. In an RCT involving 52 mostly virologically suppressed vertically infected youths aged 8 to 26 years with $25(\mathrm{OH}) \mathrm{D}$ lower than $30 \mathrm{ng} / \mathrm{mL}$, Giacomet et al. showed that 12-month supplementation with cholecalciferol 100,000 IU every 3 months resulted in reduction of antiinflammatory T-cell phenotype (i.e., decrease in $\mathrm{T}_{\mathrm{H}} 17: \mathrm{T}_{\text {reg }}$ ratio) at 3 months. This effect was no longer seen at 12 months. No significant change in baseline CD4+ cell count was observed between the treatment and placebo arms [99].

\section{Conflict of Interests}

The authors declare that there is no conflict of interests regarding the publication of this paper.

\section{References}

[1] F. J. Palella Jr., R. K. Baker, A. C. Moorman et al., "Mortality in the highly active antiretroviral therapy era: changing causes of death and disease in the HIV outpatient study," Journal of Acquired Immune Deficiency Syndromes, vol. 43, no. 1, pp. 2734, 2006.

[2] G. Maartens, C. Celum, and S. R. Lewin, "HIV infection: epidemiology, pathogenesis, treatment, and prevention," The Lancet, vol. 384, no. 9939, pp. 258-271, 2014.

[3] T. A. Rasmussen, M. Tolstrup, C. R. Brinkmann et al., "Panobinostat, a histone deacetylase inhibitor, for latent-virus reactivation in HIV-infected patients on suppressive antiretroviral therapy: a phase $1 / 2$, single group, clinical trial," The Lancet, vol. 1, no. 1, pp. e13-e21, 2014.

[4] S. G. Deeks, S. R. Lewin, and D. V. Havlir, "The end of AIDS: HIV infection as a chronic disease," The Lancet, vol. 382, no. 9903, pp. 1525-1533, 2013.

[5] J. E. Lake and J. S. Currier, "Metabolic disease in HIV infection," The Lancet Infectious Diseases, vol. 13, no. 11, pp. 964-975, 2013.

[6] V. A. Triant, "Cardiovascular disease and HIV infection," Current HIV/AIDS Reports, vol. 10, no. 3, pp. 199-206, 2013.

[7] V. Appay and D. Sauce, "Immune activation and inflammation in HIV-1 infection: causes and consequences," The Journal of Pathology, vol. 214, no. 2, pp. 231-241, 2008.

[8] J. A. Aberg, "Aging, inflammation, and HIV infection," Topics in Antiviral Medicine, vol. 20, no. 3, pp. 101-105, 2012. 
[9] D. E. Nixon and A. L. Landay, "Biomarkers of immune dysfunction in HIV," Current Opinion in HIV and AIDS, vol. 5, no. 6, pp. 498-503, 2010.

[10] N. T. Funderburg, "Markers of coagulation and inflammation often remain elevated in ART-treated HIV-infected patients," Current Opinion in HIV and AIDS, vol. 9, no. 1, pp. 80-86, 2014.

[11] National Center for Health Statistics, Centers for Disease Control and Prevention, National health and nutrition examination survey, 2014, http://www.cdc.gov/nchs/nhanes/ about_nhanes.htm.

[12] A. R. Eckard, T. Leong, A. Avery et al., "Short communication: high prevalence of vitamin D deficiency in HIV-infected and HIV-uninfected pregnant women," AIDS Research and Human Retroviruses, vol. 29, no. 9, pp. 1224-1228, 2013.

[13] S. Mehta, E. Giovannucci, F. M. Mugusi et al., "Vitamin D status of HIV-infected women and its association with hiv disease progression, anemia, and mortality," PLOS ONE, vol. 5, no. 1, Article ID e8770, 2010.

[14] D. H. Watts, "Treating HIV during pregnancy: an update on safety issues," Drug Safety, vol. 29, no. 6, pp. 467-490, 2006.

[15] M. Aziz, B. Livak, J. Burke-Miller et al., "Vitamin D insufficiency may impair CD4 recovery among Women's Interagency HIV Study participants with advanced disease on HAART," AIDS, vol. 27, no. 4, pp. 573-578, 2013.

[16] A. C. Ross, S. Judd, M. Kumari et al., "Vitamin D is linked to carotid intima-media thickness and immune reconstitution in HIV-positive individuals," Antiviral Therapy, vol. 16, no. 4, pp. 555-563, 2011.

[17] P. Wasserman and D. S. Rubin, "Highly prevalent vitamin D deficiency and insufficiency in an urban cohort of HIV-infected men under care," AIDS Patient Care and STDs, vol. 24, no. 4, pp. 223-227, 2010.

[18] K. Gedela, S. G. Edwards, P. Benn, and A. D. Grant, "Prevalence of vitamin D deficiency in HIV-positive, antiretroviral treatment-naïve patients in a single centre study," International Journal of STD \& AIDS, vol. 25, no. 7, pp. 488-492, 2014.

[19] S. M. Arpadi, D. McMahon, E. J. Abrams et al., "Effect of bimonthly supplementation with oral cholecalciferol on serum 25-hydroxyvitamin D concentrations in HIV-infected children and adolescents," Pediatrics, vol. 123, no. 1, pp. el21-e126, 2009.

[20] S. Kakalia, E. B. Sochett, D. Stephens, E. Assor, S. E. Read, and A. Bitnun, "Vitamin D supplementation and CD4 count in children infected with human immunodeficiency virus," The Journal of Pediatrics, vol. 159, no. 6, pp. 951-957, 2011.

[21] J.-P. Viard, J.-C. Souberbielle, O. Kirk et al., "Vitamin D and clinical disease progression in HIV infection: results from the EuroSIDA study," AIDS, vol. 25, no. 10, pp. 1305-1315, 2011.

[22] V. L. Vecchi, M. Soresi, L. Giannitrapani et al., "Dairy calcium intake and lifestyle risk factors for bone loss in hiv-infected and uninfected mediterranean subjects," BMC Infectious Diseases, vol. 12, article 192, 2012.

[23] C. N. Dao, P. Patel, E. T. Overton et al., "Low vitamin D among HIV-infected adults: prevalence of and risk factors for low vitamin D levels in a cohort of HIV-infected adults and comparison to prevalence among adults in the us general population," Clinical Infectious Diseases, vol. 52, no. 3, pp. 396-405, 2011.

[24] F. Havers, L. Smeaton, N. Gupte et al., "5-hydroxyvitamin D insufficiency and deficiency is associated with HIV disease progression and virological failure post-antiretroviral therapy initiation in diverse multinational settings," The Journal of Infectious Diseases, vol. 210, no. 2, pp. 244-253, 2014.
[25] A. A. Lambert, M. B. Drummond, S. H. Mehta et al., "Risk factors for vitamin D deficiency among hiv-infected and uninfected injection drug users," PLoS ONE, vol. 9, no. 4, Article ID e95802, 2014.

[26] C. E. Cherubin and J. D. Sapira, "The medical complications of drug addiction and the medical assessment of the intravenous drug user: 25 years later," Annals of Internal Medicine, vol. 119, no. 10, pp. 1017-1028, 1993.

[27] L. S. Kahn, N. Satchidanand, A. Kopparapu, W. Goh, S. Yale, and C. H. Fox, "High prevalence of undetected vitamin D deficiency in an urban minority primary care practice," Journal of the National Medical Association, vol. 103, no. 5, pp. 407-411, 2011.

[28] M. Guidi, G. Foletti, P. McLaren et al., "Vitamin D time profile based on the contribution of non-genetic and genetic factors in HIV-infected individuals of European ancestry," Antiviral Therapy, 2014.

[29] M. Theodorou, T. Sersté, M. Van Gossum, and S. Dewit, "Factors associated with vitamin D deficiency in a population of 2044 HIV-infected patients," Clinical Nutrition, vol. 33, no. 2, pp. 274-279, 2014.

[30] D. A. Wohl, C. Orkin, M. Doroana et al., "Change in vitamin $\mathrm{D}$ levels and risk of severe vitamin D deficiency over 48 weeks among HIV-1-infected, treatment-naive adults receiving rilpivirine or efavirenz in a Phase III trial (ECHO)," Antiviral Therapy, vol. 19, no. 2, pp. 191-200, 2014.

[31] N. Hariparsad, S. C. Nallani, R. S. Sane, D. J. Buckley, A. R. Buckley, and P. B. Desai, "Induction of CYP3A4 by efavirenz in primary human hepatocytes: comparison with rifampin and phenobarbital," Journal of Clinical Pharmacology, vol. 44, no. 11, pp. 1273-1281, 2004.

[32] T. T. Brown and G. A. McComsey, "Association between initiation of antiretroviral therapy with efavirenz and decreases in 25-hydroxyvitamin D," Antiviral Therapy, vol. 15, no. 3, pp. 425429, 2010.

[33] M. Ellfolk, M. Norlin, K. Gyllensten, and K. Wikvall, "Regulation of human vitamin $\mathrm{D}_{3} 25$-hydroxylases in dermal fibroblasts and prostate cancer LNCaP cells," Molecular Pharmacology, vol. 75, no. 6, pp. 1392-1399, 2009.

[34] S. A. Bozzette, C. F. Ake, H. K. Tam, S. W. Chang, and T. A. Louis, "Cardiovascular and cerebrovascular events in patients treated for human immunodeficiency virus infection," The New England Journal of Medicine, vol. 348, no. 8, pp. 702-710, 2003.

[35] N. Friis-Møller, P. Reiss, C. A. Sabin et al., "Class of antiretroviral drugs and the risk of myocardial infarction," The New England Journal of Medicine, vol. 356, no. 17, pp. 1723-1735, 2007.

[36] C. Grunfeld, J. A. Delaney, C. Wanke et al., "Preclinical atherosclerosis due to HIV infection: carotid intima-medial thickness measurements from the FRAM study," AIDS, vol. 23, no. 14, pp. 1841-1849, 2009.

[37] P. Y. Hsue, P. W. Hunt, A. Schnell et al., "Role of viral replication, antiretroviral therapy, and immunodeficiency in HIVassociated atherosclerosis," AIDS, vol. 23, no. 9, pp. 1059-1067, 2009.

[38] S. M. Crowe, C. L. V. Westhorpe, N. Mukhamedova, A. Jaworowski, D. Sviridov, and M. Bukrinsky, "The macrophage: the intersection between HIV infection and atherosclerosis," Journal of Leukocyte Biology, vol. 87, no. 4, pp. 589-598, 2010.

[39] N. Friis-Moller, R. Weber, P. Reiss, R. Thiebaut, O. Kirk, and A. d'Arminio Monforte, "Cardiovascular disease risk factors in HIV patients-association with antiretroviral therapy. Results from the DAD study," AIDS, vol. 17, no. 8, pp. 1179-1193, 2003. 
[40] M. Galli, A. L. Ridolfo, F. Adorni et al., "Body habitus changes and metabolic alterations in protease inhibitor-naive HIV-1infected patients treated with two nucleoside reverse transcriptase inhibitors," Journal of Acquired Immune Deficiency Syndromes, vol. 29, no. 1, pp. 21-31, 2002.

[41] J. L. Anderson, H. T. May, B. D. Horne et al., "Relation of vitamin $\mathrm{D}$ deficiency to cardiovascular risk factors, disease status, and incident events in a general healthcare population," The American Journal of Cardiology, vol. 106, no. 7, pp. 963-968, 2010.

[42] A. G. Pittas, M. Chung, T. Trikalinos et al., "Systematic review: vitamin D and cardiometabolic outcomes," Annals of Internal Medicine, vol. 152, no. 5, pp. 307-314, 2010.

[43] D. Santoro, G. Gagliostro, A. Alibrandi et al., "Vitamin D receptor gene polymorphism and left ventricular hypertrophy in chronic kidney disease," Nutrients, vol. 6, no. 3, pp. 1029-1037, 2014.

[44] A. Vaidya and J. S. Williams, "The relationship between vitamin $\mathrm{D}$ and the renin-angiotensin system in the pathophysiology of hypertension, kidney disease, and diabetes," Metabolism: Clinical and Experimental, vol. 61, no. 4, pp. 450-458, 2012.

[45] A. I. Choi, J. C. Lo, K. Mulligan et al., "Association of vitamin D insufficiency with carotid intima-media thickness in HIVinfected persons," Clinical Infectious Diseases, vol. 52, no. 7, pp. 941-944, 2011.

[46] J. Portilla, O. Moreno-Perez, C. Serna-Candel et al., "Vitamin $\mathrm{D}$ insufficiency and subclinical atherosclerosis in non-diabetic males living with HIV,' Journal of the International AIDS Society, vol. 17, no. 1, Article ID 18945, 2014.

[47] H. Lai, E. K. Fishman, G. Gerstenblith et al., "Vitamin D deficiency is associated with development of subclinical coronary artery disease in HIV-infected African American cocaine users with low Framingham-defined cardiovascular risk," Vascular Health and Risk Management, vol. 9, no. 1, pp. 729-737, 2013.

[48] P. Tebas, "Insulin resistance and diabetes mellitus associated with antiretroviral use in HIV-infected patients: pathogenesis, prevention, and treatment options," Journal of Acquired Immune Deficiency Syndromes, vol. 49, supplement 2, pp. S86-S92, 2008.

[49] H. Khan, S. Kunutsor, O. H. Franco, and R. Chowdhury, "Vitamin D, type 2 diabetes and other metabolic outcomes: a systematic review and meta-analysis of prospective studies," The Proceedings of the Nutrition Society, vol. 72, no. 1, pp. 89-97, 2013.

[50] Z. Szep, G. Guaraldi, S. S. Shah et al., "Vitamin D deficiency is associated with type 2 diabetes mellitus in HIV infection," AIDS, vol. 25, no. 4, pp. 525-529, 2011.

[51] O. M. Adeyemi, B. Livak, J. Orsi et al., "Vitamin D and insulin resistance in non-diabetic women's interagency HIV study participants," AIDS Patient Care and STDs, vol. 27, no. 6, pp. 320-325, 2013.

[52] C. J. P. van den Bout-van den Beukel, M. van den Bos, W. J. G. Oyen et al., "The effect of cholecalciferol supplementation on vitamin D levels and insulin sensitivity is dose related in vitamin D-deficient HIV-1-infected patients," HIV Medicine, vol. 9, no. 9, pp. 771-779, 2008.

[53] R. I. Connor and W. F. C. Rigby, " $1 \alpha, 25-$ Dihydroxyvitamin D3 inhibits productive infection of human monocytes by HIV-1," Biochemical and Biophysical Research Communications, vol. 176, no. 2, pp. 852-859, 1991.

[54] H. Schuitemaker, N. A. Kootstra, M. H. G. M. Koppelman et al., "Proliferation-dependent HIV-1 infection of monocytes occurs during differentiation into macrophages," The Journal of Clinical Investigation, vol. 89, no. 4, pp. 1154-1160, 1992.
[55] C. Haug, F. Müller, P. Aukrust, and S. S. Fræland, "Subnormal serum concentration of 1,25-vitamin D in human immunodeficiency virus infection: correlation with degree of immune deficiency and survival," The Journal of Infectious Diseases, vol. 169, no. 4, pp. 889-893, 1994.

[56] J. Teichmann, E. Stephan, T. Discher et al., "Changes in calciotropic hormones and biochemical markers of bone metabolism in patients with human immunodeficiency virus infection," Metabolism: Clinical and Experimental, vol. 49, no. 9, pp. 1134-1139, 2000.

[57] S. Mehta, F. M. Mugusi, D. Spiegelman et al., "Vitamin D status and its association with morbidity including wasting and opportunistic illnesses in HIV-infected women in Tanzania," AIDS Patient Care and STDs, vol. 25, no. 10, pp. 579-585, 2011.

[58] J. E. Sherwood, O. C. Mesner, A. C. Weintrob et al., "Vitamin $\mathrm{D}$ deficiency and its association with low bone mineral density, HIV-related factors, hospitalization, and death in a predominantly black HIV-infected cohort," Clinical Infectious Diseases, vol. 55, no. 12, pp. 1727-1736, 2012.

[59] G. L. Armstrong, A. Wasley, E. P. Simard, G. M. McQuillan, W. L. Kuhnert, and M. J. Alter, "The prevalence of hepatitis C virus infection in the United States, 1999 through 2002," Annals of Internal Medicine, vol. 144, no. 10, pp. 705-714, 2006.

[60] F. J. Torriani, M. Rodriguez-Torres, J. K. Rockstroh et al., "Peginterferon alfa-2a plus ribavirin for chronic hepatitis C virus infection in HIV-infected patients," The New England Journal of Medicine, vol. 351, no. 5, pp. 438-450, 2004.

[61] H.-H. Thein, Q. Yi, G. J. Dore, and M. D. Krahn, "Natural history of hepatitis $\mathrm{C}$ virus infection in HIV-infected individuals and the impact of HIV in the era of highly active antiretroviral therapy: a meta-analysis," AIDS, vol. 22, no. 15, pp. 1979-1991, 2008.

[62] M. W. Hull, K. Rollet, E. E. M. Moodie et al., "Insulin resistance is associated with progression to hepatic fibrosis in a cohort of HIV/hepatitis C virus-coinfected patients," AIDS, vol. 26, no. 14, pp. 1789-1794, 2012.

[63] J. Collazos, J. A. Cartón, and V. Asensi, "Gender differences in liver fibrosis and hepatitis $C$ virus-related parameters in patients coinfected with human immunodeficiency virus," Current HIV Research, vol. 9, no. 5, pp. 339-345, 2011.

[64] L. M. Villar, J. A. Del Campo, I. Ranchal, E. Lampe, and M. Romero-Gomez, "Association between vitamin D and hepatitis C virus infection: a meta-analysis," World Journal of Gastroenterology, vol. 19, no. 35, pp. 5917-5924, 2013.

[65] S. Abramovitch, L. Dahan-Bachar, E. Sharvit et al., "Vitamin $\mathrm{D}$ inhibits proliferation and profibrotic marker expression in hepatic stellate cells and decreases thioacetamide-induced liver fibrosis in rats," Gut, vol. 60, no. 12, pp. 1728-1737, 2011.

[66] L. Milazzo, C. Mazzali, G. Bestetti et al., "Liver-related factors associated with low vitamin D levels in HIV and HIV/HCV coinfected patients and comparison to general population," Current HIV Research, vol. 9, no. 3, pp. 186-193, 2011.

[67] H. Farnik, J. Bojunga, A. Berger et al., "Low vitamin D serum concentration is associated with high levels of hepatitis B virus replication in chronically infected patients," Hepatology, vol. 58, no. 4, pp. 1270-1276, 2013.

[68] M. Mandorfer, T. Reiberger, B. A. Payer et al., "Low vitamin D levels are associated with impaired virologic response to PEGIFN + RBV therapy in HIV-hepatitis C virus coinfected patients," AIDS, vol. 27, no. 2, pp. 227-232, 2013.

[69] A. D. Branch, M. Kang, K. Hollabaugh, C. M. Wyatt, R. T. Chung, and M. J. Glesby, "In HIV/hepatitis C virus co-infected 
patients, higher 25-hydroxyvitamin D concentrations were not related to hepatitis $\mathrm{C}$ virus treatment responses but were associated with ritonavir use," The American Journal of Clinical Nutrition, vol. 98, no. 2, pp. 423-429, 2013.

[70] S. Abu-Mouch, Z. Fireman, J. Jarchovsky, A.-R. Zeina, and N. Assy, "Vitamin D supplementation improves sustained virologic response in chronic hepatitis C (genotype 1)-naïve patients," World Journal of Gastroenterology, vol. 17, no. 47, pp. 5184-5190, 2011.

[71] M. Gal-Tanamy, L. Bachmetov, A. Ravid et al., "Vitamin D: an innate antiviral agent suppressing hepatitis $\mathrm{C}$ virus in human hepatocytes," Hepatology, vol. 54, no. 5, pp. 1570-1579, 2011.

[72] Y. Kondo, T. Kato, O. Kimura et al., " $1(\mathrm{OH})$ vitamin D3 supplementation improves the sensitivity of the immune-response during Peg-IFN/RBV therapy in chronic hepatitis C patientscase controlled trial," PLoS ONE, vol. 8, no. 5, Article ID e63672, 2013.

[73] C. J. Murray, K. F. Ortblad, C. Guinovart et al., "Global, regional, and national incidence and mortality for HIV, tuberculosis, and malaria during 1990-2013: a systematic analysis for the Global Burden of Disease Study 2013," The Lancet, vol. 384, no. 9947, pp. 1005-1070, 2013.

[74] S. D. Lawn, S. T. Butera, and T. M. Shinnick, "Tuberculosis unleashed: the impact of human immunodeficiency virus infection on the host granulomatous response to Mycobacterium tuberculosis," Microbes and Infection, vol. 4, no. 6, pp. 635-646, 2002.

[75] K. B. Gibney, L. MacGregor, K. Leder et al., "Vitamin D deficiency is associated with tuberculosis and latent tuberculosis infection in immigrants from sub-Saharan Africa," Clinical Infectious Diseases, vol. 46, no. 3, pp. 443-446, 2008.

[76] J. Rathored, S. K. Sharma, B. Singh et al., "Risk and outcome of multidrug-resistant tuberculosis: vitamin D receptor polymorphisms and serum 25(OH)D," The International Journal of Tuberculosis and Lung Disease, vol. 16, no. 11, pp. 1522-1528, 2012.

[77] A. R. Martineau, P. M. Timms, G. H. Bothamley et al., "Highdose vitamin D3 during intensive-phase antimicrobial treatment of pulmonary tuberculosis: a double-blind randomised controlled trial," The Lancet, vol. 377, no. 9761, pp. 242-250, 2011.

[78] C. R. Sudfeld, E. L. Giovannucci, S. Isanaka et al., "Vitamin D status and incidence of pulmonary tuberculosis, opportunistic infections, and wasting among HIV-infected tanzanian adults initiating antiretroviral therapy," The Journal of Infectious Diseases, vol. 207, no. 3, pp. 378-385, 2013.

[79] K. E. Nnoaham and A. Clarke, "Low serum vitamin D levels and tuberculosis: a systematic review and meta-analysis," International Journal of Epidemiology, vol. 37, no. 1, pp. 113-119, 2008.

[80] M. A. French, M. S. King, J. M. Tschampa, B. A. Da Silva, and A. L. Landay, "Serum immune activation markers are persistently increased in patients with HIV infection after 6 years of antiretroviral therapy despite suppression of viral replication and reconstitution of $\mathrm{CD}^{+} \mathrm{T}$ Cells," Journal of Infectious Diseases, vol. 200, no. 8, pp. 1212-1215, 2009.

[81] S. R. Ostrowski, T. L. Katzenstein, B. K. Pedersen, J. Gerstoft, and H. Ullum, "Residual viraemia in HIV-1-infected patients with plasma viral load $\leq 20$ copies/ml is associated with increased blood levels of soluble immune activation markers," Scandinavian Journal of Immunology, vol. 68, no. 6, pp. 652-660, 2008.
[82] D. A. Duprez, J. Neuhaus, L. H. Kuller et al., "Inflammation, coagulation and cardiovascular disease in HIV-infected individuals," PLoS ONE, vol. 7, no. 9, Article ID e44454, 2012.

[83] A. de Luca, K. de Gaetano Donati, M. Colafigli et al., "The association of high-sensitivity c-reactive protein and other biomarkers with cardiovascular disease in patients treated for HIV: a nested case-control study," BMC Infectious Diseases, vol. 13, no. 1, article 414, 2013.

[84] Á. H. Borges, M. J. Silverberg, D. Wentworth et al., "Predicting risk of cancer during HIV infection: the role of inflammatory and coagulation biomarkers," AIDS, vol. 27, no. 9, pp. 1433-1441, 2013.

[85] A. Biron, C. Bobin-Dubigeon, C. Volteau et al., "Metabolic syndrome in french HIV-infected patients: prevalence and predictive factors after 3 years of antiretroviral therapy," AIDS Research and Human Retroviruses, vol. 28, no. 12, pp. 1672-1678, 2012.

[86] A. C. Hearps, G. E. Martin, R. Rajasuriar, and S. M. Crowe, "Inflammatory co-morbidities in HIV+ individuals: learning lessons from healthy ageing," Current HIV/AIDS Reports, vol. 11, no. 1, pp. 20-34, 2014.

[87] K. W. Colston, L. C. Lowe, J. L. Mansi, and M. J. Campbell, "Vitamin D status and breast cancer risk," Anticancer Research, vol. 26, no. 4, pp. 2573-2580, 2006.

[88] T. Mizoue, Y. Kimura, K. Toyomura et al., "Calcium, dairy foods, vitamin D, and colorectal cancer risk: the fukuoka colorectal cancer study," Cancer Epidemiology Biomarkers \& Prevention, vol. 17, no. 10, pp. 2800-2807, 2008.

[89] A. Bakhru, J. B. Mallinger, R. J. Buckanovich, and J. J. Griggs, "Casting light on 25-hydroxyvitamin D deficiency in ovarian cancer: a study from the NHANES," Gynecologic Oncology, vol. 119, no. 2, pp. 314-318, 2010.

[90] G. G. Schwartz, "Vitamin D and intervention trials in prostate cancer: from theory to therapy," Annals of Epidemiology, vol. 19, no. 2, pp. 96-102, 2009.

[91] K. M. Erlandson, I. Gudza, S. Fiorillo et al., "Relationship of vitamin D insufficiency to AIDS-associated Kaposi's sarcoma outcomes: retrospective analysis of a prospective clinical trial in Zimbabwe," International Journal of Infectious Diseases, vol. 24, pp. 6-10, 2014.

[92] EACSEACSgpamon-iciHOA, 2014, http://www.eacsociety.org/ Portals/0/Guidelines_Online_131014.pdf.

[93] G. A. McComsey, P. Tebas, E. Shane et al., "Bone disease in HIV infection: a practical review and recommendations for HIV care providers," Clinical Infectious Diseases, vol. 51, no. 8, pp. 937946, 2010.

[94] M. Chung, J. Lee, T. Terasawa, J. Lau, and T. A. Trikalinos, "Vitamin D with or without calcium supplementation for prevention of cancer and fractures: an updated meta-analysis for the U.S. preventive services task force," Annals of Internal Medicine, vol. 155, no. 12, pp. 827-838, 2011.

[95] M. F. Holick, "Medical progress: vitamin D deficiency," The New England Journal of Medicine, vol. 357, no. 3, pp. 266-281, 2007.

[96] V. Groleau, R. A. Herold, J. I. Schall et al., "Blood lead concentration is not altered by high-dose vitamin $\mathrm{D}$ supplementation in children and young adults with HIV,' Journal of Pediatric Gastroenterology \& Nutrition, vol. 56, no. 3, pp. 311-315, 2013.

[97] A. S. Ettinger, H. Lamadrid-Figueroa, M. M. Téllez-Rojo et al., "Effect of calcium supplementation on blood lead levels in pregnancy: a randomized placebo-controlled trial," Environmental Health Perspectives, vol. 117, no. 1, pp. 26-31, 2009. 
[98] C. T. Longenecker, C. O. Hileman, T. L. Carman et al., "Vitamin $\mathrm{D}$ supplementation and endothelial function in vitamin D deficient HIV-infected patients: a randomized placebo-controlled trial," Antiviral Therapy, vol. 17, no. 4, pp. 613-621, 2012.

[99] V. Giacomet, A. Vigano, V. Manfredini et al., "Cholecalciferol supplementation in HIV-infected youth with vitamin d insufficiency: effects on vitamin d status and t-cell phenotype: a randomized controlled trial," HIV Clinical Trials, vol. 14, no. 2, pp. 51-60, 2013. 


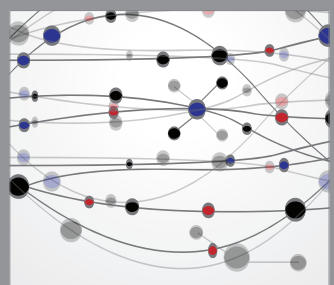

The Scientific World Journal


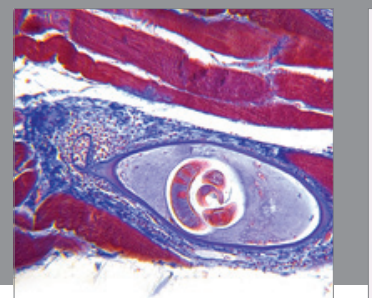

Gastroenterology

Research and Practice
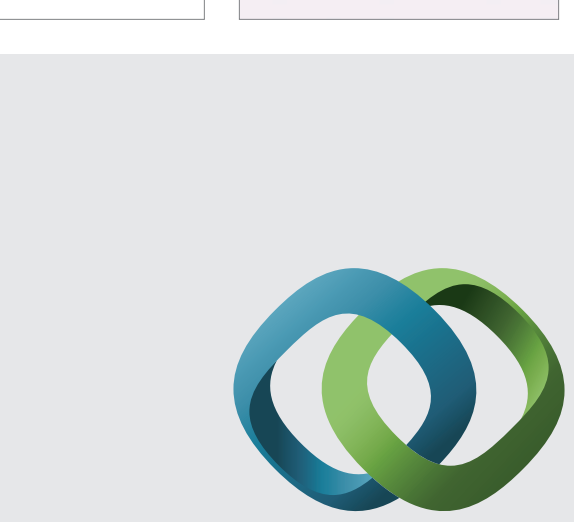

\section{Hindawi}

Submit your manuscripts at

http://www.hindawi.com
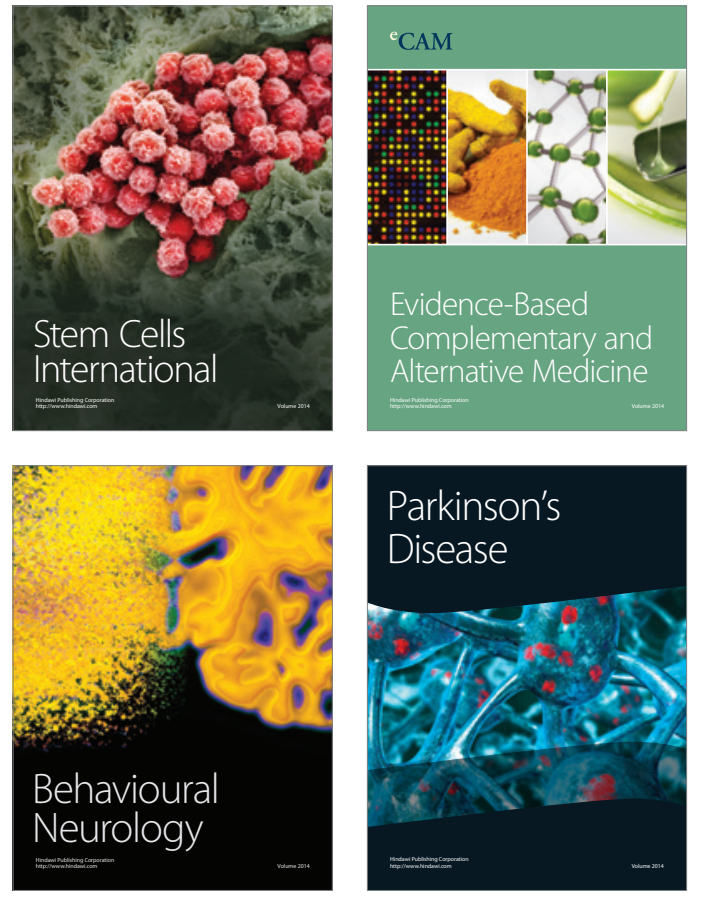
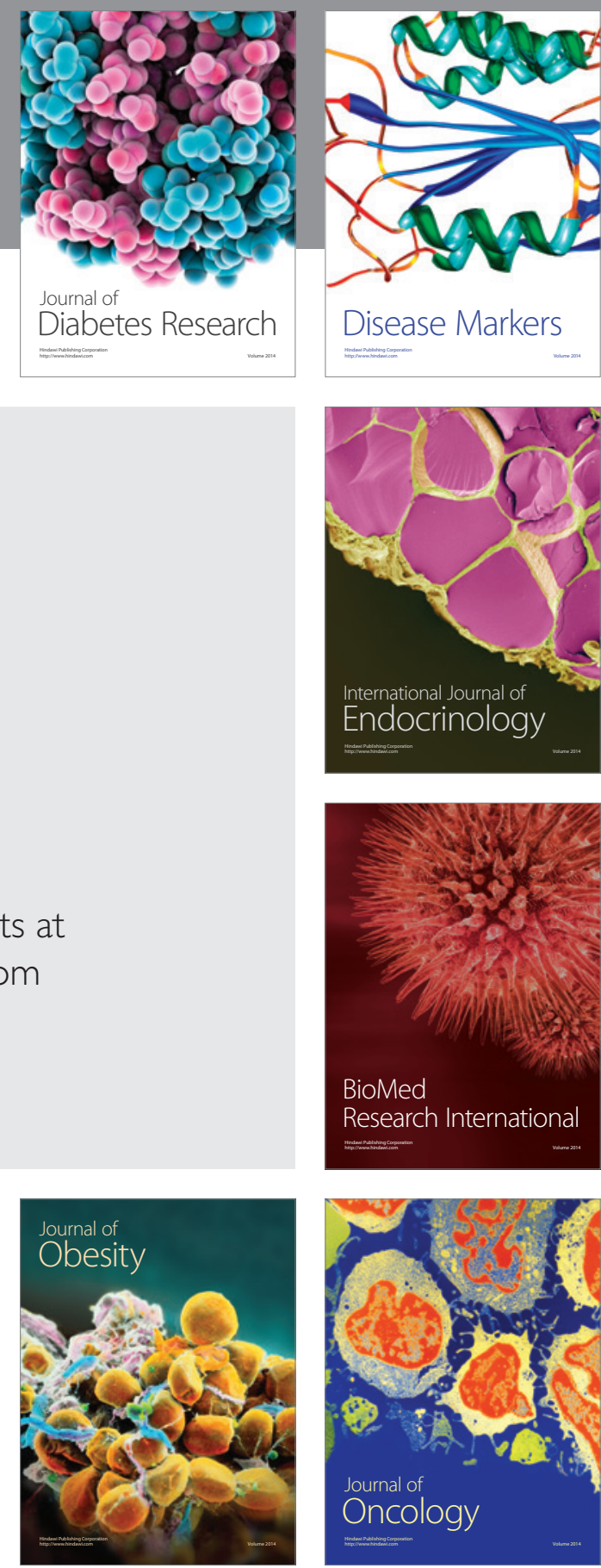

Disease Markers
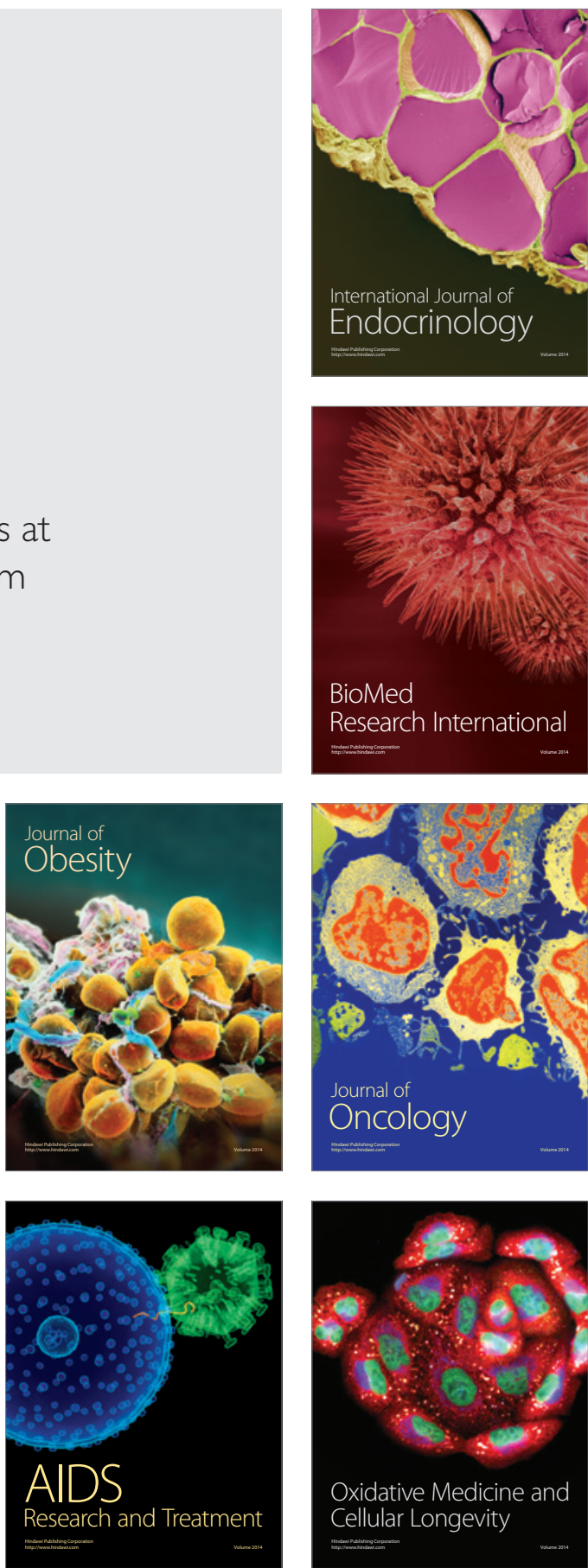